\title{
Phylogeography and genetic diversity of the Robin (Erithacus rubecula) in the Azores Islands: Evidence of a recent colonisation
}

\author{
Pedro Rodrigues $\cdot$ Ricardo Jorge Lopes • \\ Sergei V. Drovetski $\cdot$ Sandra Reis $\cdot$ Jaime A. Ramos • \\ Regina Tristão da Cunha
}

Received: 9 April 2012/Revised: 28 January 2013/Accepted: 2 April 2013/Published online: 25 April 2013

(c) Dt. Ornithologen-Gesellschaft e.V. 2013

\begin{abstract}
We present new insights into the phylogeography of the Robin, Erithacus rubecula, from the seven Azores Islands where it breeds, based on sequences of mitochondrial and nuclear genes from 35 individuals (five from each of the seven islands) as well as outgroup/comparison samples from Madeira, Canary Islands and Continental Western Palearctic (Europe and North Africa). To understand the level of concordance between the genetic data and morphometric variability, eight morphometric characters were analysed for 113 birds for the seven Azores Islands populations. Our results revealed that Robins from the Azores possess low genetic diversity and share their most common haplotype with Madeira and the Continental
\end{abstract}

Communicated by M. Wink.

Electronic supplementary material The online version of this article (doi:10.1007/s10336-013-0953-4) contains supplementary material, which is available to authorized users.

P. Rodrigues $(\varangle) \cdot$ R. T. da Cunha

CIBIO, Centro de Investigação em Biodiversidade e Recursos Genéticos, InBIO Laboratório Associado, Polo dos Açores, Universidade dos Açores, 9501-801 Ponta Delgada, Portugal e-mail: pedrorodrigues@uac.pt

R. J. Lopes · S. Reis

CIBIO, Centro de Investigação em Biodiversidade e Recursos Genéticos da Universidade do Porto, InBIO Laboratório Associado, Universidade do Porto, Campus Agrário de Vairão, 4485-661 Vairão, Portugal

S. V. Drovetski

Tromsø University Museum, 9037 Tromsö, Norway

\section{J. A. Ramos}

Institute of Marine Research (IMAR/CMA), Department of Life Sciences, University of Coimbra, Apartado 3046,

3001-401 Coimbra, Portugal
Western Palearctic Robins, which support the hypothesis of one recent founder event and a fast range expansion to most of the Azores Islands. Nevertheless, despite this lack of neutral genetic differentiation, morphological differences were found among islands, which could be attributed to natural selection processes. The morphological data show that birds from São Miguel had the longest wings and largest body mass, and that birds from Graciosa had the smallest bill length. This recent colonisation could be the reason for the absence of Robins in the westernmost islands of the Azores.

Keywords Robin - Erithacus rubecula Azores · Islands . Phylogeography $\cdot$ Biometrics

\section{Zusammenfassung}

Phylogeographie und genetische Diversität des Rotkehlchens (Erithacus rubecula) auf den Azoren: Hinweise auf eine kürzlich erfolgte Besiedlung

Wir stellen neue Erkenntnisse zur Phylogeographie des Rotkehlchens (Erithacus rubecula) auf den sieben Azoreninseln, auf denen es brütet, vor, die auf den Sequenzen mitochondrialer und nukleärer Gene von 35 Individuen (fünf von jeder Insel) sowie Außengruppen-/Vergleichsproben aus Madeira, den Kanaren und der kontinentalen westlichen Paläarktis (Europa und Nordafrika) basieren. Um das Ausmaß der Übereinstimmung zwischen den genetischen Daten und der morphometrischen Variabilität zu verstehen, haben wir acht morphometrische Merkmale für 113 Vögel aus den sieben Azoreninselpopulationen analysiert. Unsere Ergebnisse zeigten, dass Rotkehlchen von den Azoren eine niedrige genetische Diversität aufweisen und den häufigsten Haplotyp mit den Rotkehlchen aus 
Madeira und der kontinentalen westlichen Paläarktis teilen, was die Hypothese eines kürzlich erfolgten Besiedlungsereignisses und einer schnellen Ausweitung des Verbreitungsgebiets auf die meisten Azoreninseln stützt. Trotz dieses Mangels an neutraler genetischer Differenzierung wurden morphometrische Unterschiede zwischen den Inseln gefunden, die auf natürliche Selektionsprozesse zurückgeführt werden konnten. Die morphologischen Daten zeigen, dass Vögel aus São Miguel die längsten Flügel sowie die größte Körpermasse und Vögel aus Graciosa die kürzesten Schnäbel aufwiesen. Diese erst kürzlich erfolgte Besiedlung könnte der Grund dafür sein, dass Rotkehlchen auf den westlichsten Azoreninseln fehlen.

\section{Introduction}

Understanding the evolutionary processes in oceanic island populations has been a central theme in avian evolution. In the last two decades, several studies about the phylogeography and/or population genetics of avian species inhabiting the Macaronesian Islands (the Azores, Madeira, and the Canary Islands) were published, e.g., Stonechats, Saxicola torquata (Wittmann et al. 1995; Wink et al. 2002) Berthelot's pipits, Anthus berthelotti (Arctander et al. 1996), Chiffchaffs, Phylloscopus collybita (Helbig et al. 1996), Chaffinches, Fringilla coelebs (Marshall and Baker 1999; Suárez et al. 2009), Goldcrests, Regulus regulus (Päckert and Martens 2004; Päckert et al. 2006), Island Canary, Serinus canaria (Dietzen et al. 2006), and Blue tits, Cyanistes sp. (Illera et al. 2011). The Robin, Erithacus rubecula, is one of the west Palearctic species which breeds from the western Siberia to the Atlantic coast and in the biogeographic region of Macaronesia (del Hoyo et al. 2006). Three subspecies of Robins are recognized in this group of Atlantic islands: E. r. superbus in Tenerife, E. $r$. marionae in Gran Canaria and the European nominate $E$. $r$. rubecula in the western Canary Islands, Madeira, and the Azores (Bergmann and Schottler 2001; del Hoyo et al. 2006; Rodrigues et al. 2010).

The phylogeography and the status of the Canary Islands Robin subspecies were assessed by Dietzen et al. (2003), who used sequences of the mitochondrial DNA (mtDNA) Cytochrome-b (CYTB) gene and morphometrics, but the current taxonomy of the Robin on Madeira and on the Azores is based only on morphological variation, in particular the plumage coloration differences, which often are subjective and poorly defined (Hartert and Olgivie-Grant 1905; Bannerman and Bannerman 1966; Cramp 1988; Clements 2000). For example, the Robins from Azores, Madeira and the western Canary Islands (La Gomera, El
Hierro and La Palma) have been formerly regarded as a different subspecies E. r. microrhynchos (Hounsome 1993; Martin and Lorenzo 2001), but are presently included in rubecula (Clements 2000; Clarke et al. 2006). Bannerman and Bannerman (1966) suggested that the Azorean Robin could belong to a different race than the continental species, due to the more vivid red breast of the former. The Azorean Robin is a common resident bird that breeds in forested areas from sea level to about $800 \mathrm{~m}$ elevation on all Azorean islands except the two westernmost ones, Flores and Corvo, where it does not breed (Clarke et al. 2006; Equipa Atlas 2008).

Molecular genetics provides robust data that are not impaired by convergent evolution to the same degree as morphological data. Additionally, it provides a temporal estimation for each evolutionary step and, consequently, allows both phylogenetic and geographical analysis of island biota (Wink et al. 2002). For the first time, we analysed the phylogeography and genetic structure of the Azorean Robin populations based on sequences of two mtDNA and one nuclear gene. To understand the level of concordance between molecular data and morphometric variability, eight morphometric characters were measured and analysed for 113 Robins from the same Azorean populations.

\section{Materials and methods}

\section{Study area}

The Azores archipelago is located between latitudes $36^{\circ} 55^{\prime}$ and $39^{\circ} 43^{\prime}$ North, and longitudes $24^{\circ} 46^{\prime}$ and $31^{\circ} 16^{\prime}$ West, about $1,500 \mathrm{~km}$ from Europe and 1,900 km from North America (Fig. 1). The Azores consists of nine islands of recent volcanic origin (island ages range between 0.3 and 8 million years), which spread over more than $600 \mathrm{~km}$ along a northwest-southeast axis (França et al. 2003). They geographically cluster into three groups: (1) the western group (Flores and Corvo); (2) the central group (Faial, Pico, São Jorge, Terceira and Graciosa); (3) and the eastern group (São Miguel and Santa Maria). The distribution of the Robin is restricted to the eastern and central groups.

Field sampling

Live birds were captured with mist nets on the seven islands of the Azores where this species breeds, during four consecutive years (2008-2011). Individuals were ringed and measured, and blood samples were taken from the brachial vein. The birds were released and the blood samples preserved in $96 \%$ ethanol for further processing. 


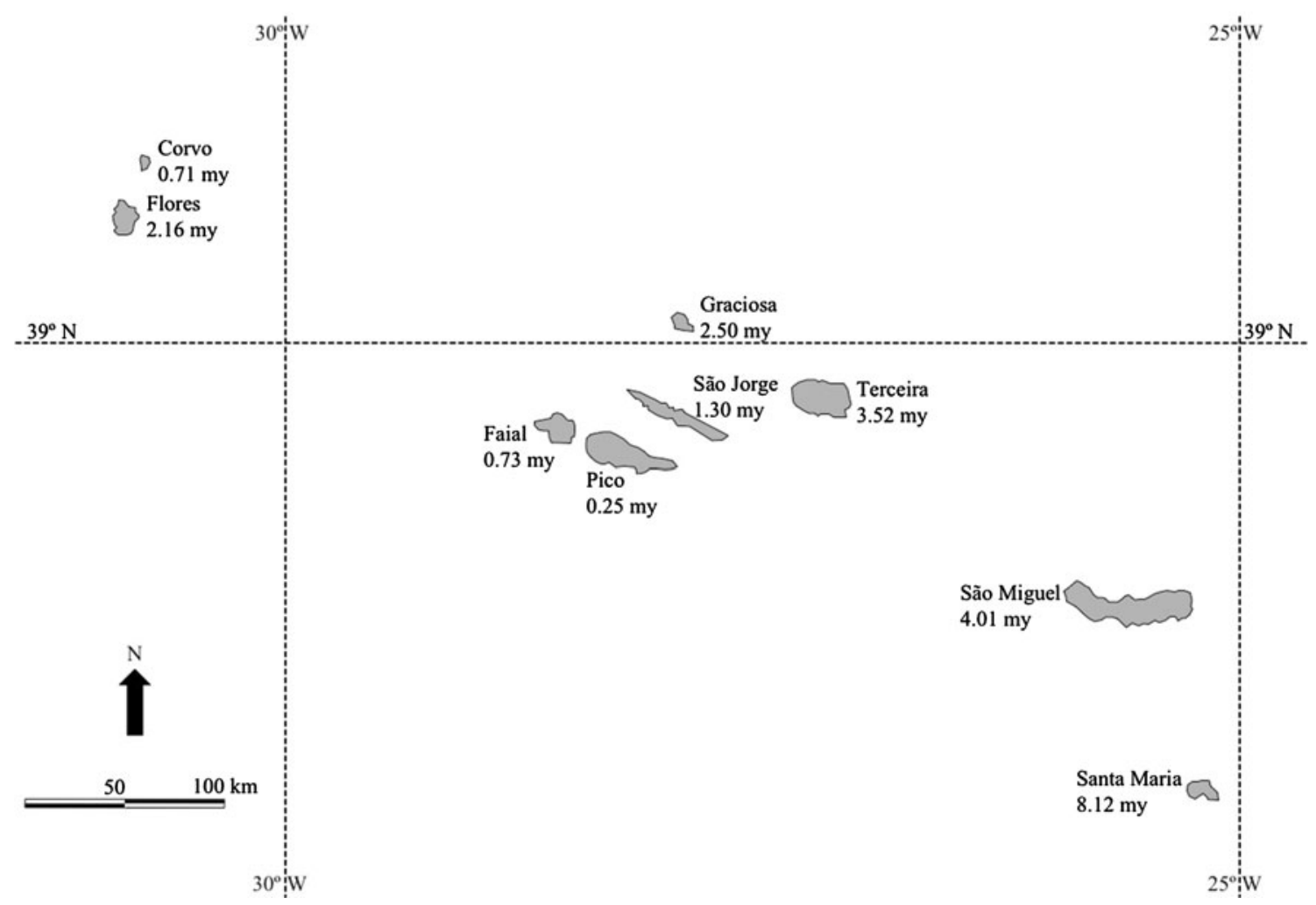

Fig. 1 Map and maximum isotopic age of the Azores islands. The Robin Erithacus rubecula is present on Santa Maria, São Miguel, Terceira, Graciosa, São Jorge, Pico and Faial islands

Genetic data

Genomic DNA was extracted from blood samples of 35 Azorean Robins (five from each of the seven islands) as well as from samples from Madeira and the Continental Western Palearctic (Europe and North Africa) (see Online Resource 1 for sample details) using the DNeasy Blood and Tissue Kit (Qiagen, Netherlands) and following the manufacturer instructions. For each sample, two mtDNA genes, the NADH dehydrogenase subunit 2 (ND2) and the Cytochrome $b$ (CYTB), and the intron 9 of the Aconitase 1 gene (ACO1) located on the Z-chromosome, were amplified by polymerase chain reaction (PCR). Primers and PCR conditions are described in Online Resource 2.

All sequencing reactions were run on a 3730xl Genetic Analyzer (Applied Biosystems, USA) by Macrogen Europe (Amsterdam, Netherlands) and results were edited and assembled in Geneious 5.5 (Biomatters, New Zealand). For the nuclear loci, we used DnaSP 5.10.01 (Librado and Rozas 2009) to resolve the haplotypes from the unphased genotype data when a sequence contained multiple heterozygous sites. All sequences were deposited in GenBank (Accession numbers-ND2: JX170796 to JX170866; CYTB: JX206831 to 206880; ACO1: JX206881 to JX206967).
Genetic diversity and phylogenetic analyses

Genetic diversity was quantified for the Azores and separately for each island by estimating the number of haplotypes $(\mathrm{H})$, haplotype diversity $(\mathrm{Hd})$, substitution sites $(\mathrm{S})$, nucleotide diversity $\left(\pi_{\mathrm{n}}\right)$, and theta mutation parameter $(\theta)$ corresponding to $4 \mathrm{~N} \mu$, where $\mathrm{N}$ is the effective population size and $\mu$ is the neutral mutation rate per generation (Nei 1987). Non-parametric Mann-Whitney tests were used to compare levels of diversity from the Azores with the outgroups. Using DnaSP 5.10.01 (Librado and Rozas 2009), we tested whether island populations experienced selection evaluating departures from neutrality using Fu's (Fs) (Fu 1997), Fu and Li's D* (Fu and Li 1993), Tajima's (D) (Tajima 1989, 1996) and R2 (Ramos-Onsins and Rozas 2002) neutrality tests. We tested for recent demographic expansion using pairwise mismatch distributions and the expected values in a stable population, i.e., population with constant population size and in growing or declining populations. The raggedness statistic, r (Harpending 1994), was also estimated to test the smoothness of the observed pairwise differences distribution. The expansion coefficient (ratio of variable sequence positions relative to the mean number of pairwise nucleotide differences) was also calculated based on Peck and Congdon (2004). Recent 
population expansion is indicated by large values and constant long-term population size is indicated by small values (von Haeseler et al. 1996). We also used a group of samples of CYTB from the Canary Islands available in GenBank (see Online Resource 1).

Genetic differentiation was tested using analysis of molecular variance (AMOVA) and pairwise Fst values were compared among populations (Azores was divided in two groups of samples: (1), the Central group and (2), the Oriental group), performed in Arlequin 2.0 (Schneider et al. 2000). We used AMOVA to test for differentiation among the Azores populations and between the Azores and the more distant populations from Madeira, Canary Islands (only for CYTB) and Continental Western Palearctic.

Table 1 Samples sizes $(\mathrm{N})$ and gene diversity estimates for the study

\begin{tabular}{|c|c|c|c|c|c|c|c|c|}
\hline Island/region & $\mathrm{N}$ & $\mathrm{H}$ & $\mathrm{Ph}$ & $\mathrm{Hd} \pm \mathrm{SD}$ & $\pi_{\mathrm{n}} \pm \mathrm{SD}$ & $\mathrm{S}$ & $\mathrm{Tt}: \mathrm{Tv}$ & $\mathrm{K}$ \\
\hline \multicolumn{9}{|c|}{ CYTB (619 sites, 10 variable sites, 3 parsimony informative sites) } \\
\hline Azores & 35 & 2 & 1 & $0.1 \pm 0.05$ & $0.00009 \pm 0.0001$ & 1 & $1: 0$ & 0.1 \\
\hline Faial & 5 & 1 & 0 & 0.0 & 0 & 0 & 0 & 0.0 \\
\hline Pico & 5 & 1 & 0 & 0.0 & 0 & 0 & 0 & 0.0 \\
\hline São Jorge & 5 & 2 & 1 & $0.4 \pm 0.24$ & $0.00065 \pm 0.0004$ & 1 & $1: 0$ & 0.4 \\
\hline Graciosa & 5 & 1 & 0 & 0.0 & 0 & 0 & 0 & 0.0 \\
\hline Terceira & 5 & 1 & 0 & 0.0 & 0 & 0 & 0 & 0.0 \\
\hline São Miguel & 5 & 1 & 0 & 0.0 & 0 & 0 & 0 & 0.0 \\
\hline Santa Maria & 5 & 1 & 0 & 0.0 & 0 & 0 & 0 & 0.0 \\
\hline Madeira & 5 & 3 & 2 & $0.8 \pm 0.16$ & $0.00258 \pm 0.0006$ & 3 & $3: 0$ & 1.6 \\
\hline Canary Islands & 53 & 9 & 7 & $0.8 \pm 0.02$ & $0.02526 \pm 0.0012$ & 40 & $38: 2$ & 15.5 \\
\hline Continental Western Palearctic & 15 & 8 & 6 & $0.9 \pm 0.07$ & $0.00215 \pm 0.0004$ & 7 & $7: 0$ & 1.3 \\
\hline Mann-Whitney (U) & & $0.00 *$ & & $0.00 *$ & $0.00 *$ & $0.00 *$ & & $0.00 *$ \\
\hline \multicolumn{9}{|c|}{ ND2 (1,041 sites, 10 variable sites, 1 parsimony informative sites) } \\
\hline Azores & 35 & 1 & 0 & 0.0 & 0 & 0 & 0 & 0.0 \\
\hline Faial & 5 & 1 & 0 & 0.0 & 0 & 0 & 0 & 0.0 \\
\hline Pico & 5 & 1 & 0 & 0.0 & 0 & 0 & 0 & 0.0 \\
\hline São Jorge & 5 & 1 & 0 & 0.0 & 0 & 0 & 0 & 0.0 \\
\hline Graciosa & 5 & 1 & 0 & 0.0 & 0 & 0 & 0 & 0.0 \\
\hline Terceira & 5 & 1 & 0 & 0.0 & 0 & 0 & 0 & 0.0 \\
\hline São Miguel & 5 & 1 & 0 & 0.0 & 0 & 0 & 0 & 0.0 \\
\hline Santa Maria & 5 & 1 & 0 & 0.0 & 0 & 0 & 0 & 0.0 \\
\hline Madeira & 5 & 2 & 1 & $0.6 \pm 0.18$ & $0.00058 \pm 0.0002$ & 1 & $1: 0$ & 0.6 \\
\hline Continental Western Palearctic & 31 & 20 & 19 & $0.9 \pm 0.06$ & $0.00190 \pm 0.0003$ & 26 & 26:0 & 2.0 \\
\hline Mann-Whitney (U) & & $0.00 *$ & & $0.00 *$ & $0.00 *$ & $0.00 *$ & & $0.00 *$ \\
\hline \multicolumn{9}{|c|}{ ACO1 (892 sites, 16 variable sites, 9 parsimony informative sites) } \\
\hline Azores & 35 & 5 & 2 & $0.7 \pm 0.04$ & $0.00399 \pm 0.0005$ & 9 & $6: 3$ & 3.5 \\
\hline Faial & 5 & 3 & 0 & $0.7 \pm 0.16$ & $0.00331 \pm 0.0017$ & 8 & $6: 2$ & 2.9 \\
\hline Pico & 5 & 4 & 0 & $0.8 \pm 0.13$ & $0.00473 \pm 0.0014$ & 9 & $6: 3$ & 4.2 \\
\hline São Jorge & 5 & 2 & 0 & $0.3 \pm 0.22$ & $0.00301 \pm 0.0019$ & 8 & $6: 2$ & 2.7 \\
\hline Graciosa & 5 & 2 & 0 & $0.4 \pm 0.24$ & $0.00316 \pm 0.0019$ & 7 & $5: 2$ & 2.8 \\
\hline Terceira & 5 & 3 & 0 & $0.7 \pm 0.13$ & $0.00516 \pm 0.0010$ & 8 & $6: 2$ & 4.6 \\
\hline São Miguel & 5 & 4 & 0 & $0.8 \pm 0.14$ & $0.00424 \pm 0.0014$ & 9 & $6: 3$ & 3.8 \\
\hline Santa Maria & 5 & 5 & 0 & $0.8 \pm 0.13$ & $0.00548 \pm 0.0010$ & 9 & $6: 3$ & 4.9 \\
\hline Madeira & 5 & 2 & 0 & $0.5 \pm 0.12$ & $0.00484 \pm 0.0011$ & 8 & $6: 2$ & 4.3 \\
\hline Continental Western Palearctic & 30 & 12 & 10 & $0.8 \pm 0.05$ & $0.00609 \pm 0.0004$ & 20 & $8: 12$ & 5.3 \\
\hline Mann-Whitney (U) & & 6.00 & & 6.50 & 2.00 & 4.50 & & 2.00 \\
\hline
\end{tabular}

Number of haplotypes $(\mathrm{H})$ and of private haplotypes $(\mathrm{Ph})$, haplotype diversity with standard deviation (Hd $\pm \mathrm{SD}$ ), nucleotide diversity with standard deviation $\left(\pi_{\mathbf{n}} \pm \mathrm{SD}\right)$, number of substitutions $(\mathrm{S})$ with ratio transitions versus transversions (Tt:Tv) and mean pairwise nucleotide differences $(\mathrm{K})$

Mann-Whitney (U) values are shown and significance levels are denoted in bold $\left(P<0.05^{*}\right)$ 
Genetic structure was visualized with a statistical parsimony haplotype network that was constructed using TCS 1.21 (Clement et al. 2000). The ND2 and ACO1 networks were based on samples from the Azores, Madeira and Continental Western Palearctic. The CYTB network was also based on samples form the Azores, Madeira and Continental Western Palearctic (Portugal and Morocco), and an additional outgroup of samples from the Canary Islands, Portugal and Germany available in Genbank (see Online Resource 1 for sample details). Indels were coded as a single 5th character state regardless of its length.

\section{Morphometrics}

We analysed morphological variation in eight morphometric variables among 113 nonmoulting birds. These characters were measured following Svensson (1992): wing length (measured as the maximum length of the flattened and straightened wing), tail length (from the base of the two central tail feathers to the tip of the longest tail feathers), tarsus length (measured from the notch of the intertarsal joint to the lower edge of the last scale), bill length (from tip to skull), head and bill length (from the tip to the back of the skull), bill height (from the base of lower mandible to the top of the upper mandible, at the proximal top edge of the nostril), bill width (measured perpendicular to the bill, along the top edge of the nostril) and body mass. Wing and tail were measured using a ruler (precision $1 \mathrm{~mm}$ ), bill and tarsus measurements were made with a calliper (precision $0.1 \mathrm{~mm}$ ) and body mass was obtained using a digital scale (precision $0.1 \mathrm{~g}$ ). All measurements were taken by the same person (P. Rodrigues).

Due to our reduced number of confirmed females (with visible incubation patch), it was not possible to distinguish between sexes, and thus we consider our samples as a single group (following Pérez-Tris et al. 2000). We used a
MANOVA (Zar 1999), followed by a Tukey post hoc test, to perform a multivariate analysis of the morphometric variables among islands. To analyse morphological differentiation among island populations, we used Canonical Discriminant Analysis (CDA) as an exploratory multivariate method (Thompson 1991). The percentages of scores classified correctly into their respective island were used to indicate the effectiveness of the CDA. All analyses were performed with STATISTICA 8.0 (StatSoft Inc. 2007).

\section{Results}

Genetic diversity

In general, the diversity parameters, such as number of haplotypes $(\mathrm{H})$, haplotype diversity $(\mathrm{Hd})$, nucleotide diversity $\left(\pi_{n}\right)$, substitution sites $(S)$, and nucleotide differences $(\mathrm{K})$ were always smaller in the Azores populations than in Madeira, Canary Islands and Continental Western Palearctic for the mitochondrial genes (Mann-Whitney $U=0.00, P=0.05)$, but were similar for the Z-specific intron (Mann-Whitney $U=2.00-6.50, P=0.14-0.88$ ). All diversity parameters were similar among the Azores islands. The genetic diversity of the birds from Madeira was intermediate between those of the Azores and continental Palearctic while the Canary populations presented the highest levels of genetic diversity (Table 1).

There was significant evidence for deviation from the neutrality in the CYTB gene for the Canary Islands samples, which could reveal population structure, selective pressures or random drift. The Continental Western Palearctic samples had significant negative values of Tajima's $D$ and Fu's $F s$ in the ND2 gene, revealing a recent expansion. For the nuclear loci, the Azores samples had significant positive values of Tajima's $D$ and Fu's $F s$, and

Table 2 Expansion indices for the studied populations: expansion coefficient (S/k), Tajima's $D$, Fu's $F s$, Fu and Li's $D^{*}$, Raggedness $r$, and Ramons-Onsins and Rozas $R 2$ values

\begin{tabular}{|c|c|c|c|c|c|c|c|}
\hline Gene & Region & $\mathrm{S} / \mathrm{k}$ & $D$ & Fs & $D^{*}$ & $R$ & $R 2$ \\
\hline \multirow[t]{4}{*}{ CYTB } & Azores & 10.00 & -1.14 & -1.34 & -1.73 & 0.79 & 0.17 \\
\hline & Madeira & 1.88 & 0.70 & 0.28 & 0.70 & 0.12 & 0.24 \\
\hline & Canary Islands & 2.65 & $2.47 *$ & $14.41 * *$ & 1.31 & 0.09 & 0.19 \\
\hline & Continental Western Palearctic & 4.29 & -1.49 & -4.64 & -1.51 & 0.19 & 0.09 \\
\hline \multirow[t]{3}{*}{ ND2 } & Azores & - & - & - & - & - & - \\
\hline & Madeira & 1.67 & 1.23 & 0.63 & 1.23 & 0.40 & 0.30 \\
\hline & Continental Western Palearctic & 13.00 & $-2.47 * *$ & $-20.46 * * *$ & $-3.61 *$ & 0.05 & 0.04 \\
\hline \multirow[t]{3}{*}{ ACO1 } & Azores & 2.57 & $2.07 *$ & $6.29 *$ & 1.36 & 0.13 & 0.20 \\
\hline & Madeira & 1.86 & 1.88 & $6.06 *$ & $1.47 *$ & 0.79 & 0.27 \\
\hline & Continental Western Palearctic & 3.77 & 0.24 & -0.43 & -0.30 & 0.06 & 0.13 \\
\hline
\end{tabular}

Significance levels are denoted in bold $(* P<0.05$, ** $P<0.01$, *** $P<0.001)$ 
the Madeira samples also had positive values of Fu's $F s$ and $\mathrm{Fu}$ and $\mathrm{Li}$ 's $D^{*}$, which could indicate balancing selection and/or a population size decrease in both regions (Table 2). The pairwise mismatch distribution for the CYTB gene had a multimodal shape for all regions, indicating two classes of comparison, within and between regions, while the Azores had a clear unimodal shape, also observed in ND2 for all the studied regions, typical for recent population expansions. In the case of ACO1 the pairwise mismatch distributions had bimodal shapes, corresponding to the presence of two haplogroups. This could indicate some structure resulting from a long-term stable population size or a bottleneck, most likely before the arrival of Robins to the Azores (Fig. 2).

Haplotype diversity within the Azores was very low for all loci. The Azores populations had two different haplotypes; CYTB_01 which was shared with Madeira, the Canary Islands and Continental Western Palearctic, and CYTB_02 which was present in only one individual on São Jorge. For the ND2 gene, we obtained one unique haplotype (ND2_01) that was shared with Madeira and Continental Western Palearctic. For the ACO1 gene, we obtained five
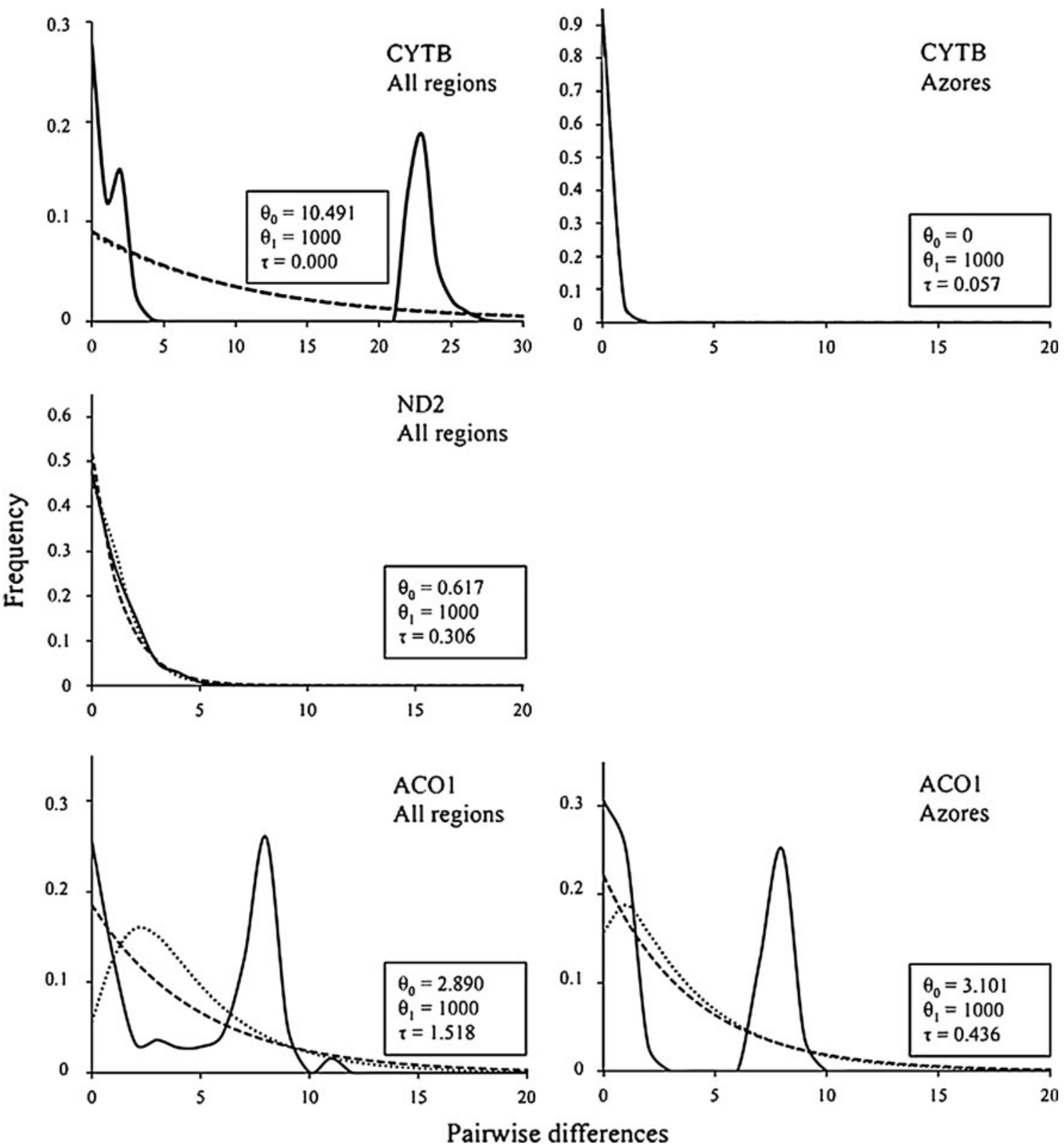

Fig. 2 Pairwise mismatch distributions of DNA genes sequence data of Erithacus rubecula. Solid lines observed; dashed lines expected in a constant population size; dotted lines expected in a expansion population size. In the box, model for expected values in a population growth/decline: $\theta_{0} \_$Theta initial; $\theta_{1} \_$Theta final; $\mathrm{T}-\mathrm{Tau}$ 
different haplotypes (ACO1_01, 02, 05, 06 and 07). ACO1_01 was shared with all the other regions, ACO1_05 was shared with Madeira and Continental Western Palearctic, and ACO1_06 was shared with Continental Western Palearctic (see Online Resource 1 and 3).

The AMOVA showed that variation among individuals within populations explained a significant proportion of the observed variance (Table 3). The same was true for CYTB and ACO1 when only the Azorean Islands were used in the AMOVA, and there was no variation in ND2 sequences. The Fst values (Table 4) between Robin populations from oriental group and central group of the Azores and between all the Azores islands and Madeira were not significant for all the genes. The Azores was significantly different from the Continental Western Palearctic and from the Canary Islands; the Azores oriental group was not significantly different from the western Canary Islands (La Palma, El Hierro and La Gomera). Madeira was only different from Gran Canaria and Tenerife, and Continental Western
Palearctic was significantly different from the Canary Islands. The three groups within the Canary Islands were also significantly different from each other (Table 4).

\section{Haplotype networks}

The CYTB network showed three different populations of Robins in the Canary Islands: populations from Gran Canaria and Tenerife are very distant from the rest of the other populations (more than 20 mutational steps), and that Azores, Madeira, part of the Canary Islands and Continental Western Palearctic samples are closely related to each other (Fig. 3). Both the ND2 and the CYTB genes showed a similar "star" shape typical of recent expansions, except for Gran Canaria and Tenerife in CYTB network. Although the structure of the ACO1 network was more complex, Azorean localities shared common haplotypes with Madeira and continental Palearctic populations.

Table 3 Analysis of molecular variance results indicating the percentage of variance among groups and populations. Significant levels are shown in bold

\begin{tabular}{|c|c|c|c|c|c|c|c|}
\hline Gene & Source of variation & $d f$ & $\begin{array}{l}\text { Sum of } \\
\text { squares }\end{array}$ & $\begin{array}{l}\text { Variance } \\
\text { components }\end{array}$ & $\begin{array}{l}\text { Percentage of } \\
\text { variance }\end{array}$ & $P$ value & $F$ statistics \\
\hline \multirow[t]{9}{*}{ CYTB } & \multicolumn{7}{|c|}{ Groups: Azores, Madeira, Canary Islands, Continental Western Palearctic } \\
\hline & Among groups & 4 & 8.128 & 0.1343 & 35 & 0.008 & FCT: 0.3497 \\
\hline & Among populations within groups & 5 & 0.160 & -0.0544 & -14 & 1.000 & FSC: -0.2180 \\
\hline & Within populations & 98 & 29.805 & 0.3041 & 79 & $<\mathbf{0 . 0 0 1}$ & FST: 0.2080 \\
\hline & Total & 107 & 38.093 & 0.3841 & & & \\
\hline & \multicolumn{7}{|l|}{ Only Azores populations } \\
\hline & Among populations & 6 & 0.171 & 0.000 & 0 & 1.000 & FST: $<0.001$ \\
\hline & Within populations & 28 & 0.800 & 0.0286 & 100 & & \\
\hline & Total & 34 & 0.971 & 0.0286 & & & \\
\hline \multirow[t]{9}{*}{ ND2 } & \multicolumn{7}{|c|}{ Groups: Azores, outgroup (Madeira, Continental Western Palearctic) } \\
\hline & Among groups & 1 & 3.492 & 0.1188 & 38 & 0.003 & FCT: 0.385 \\
\hline & Among populations within groups & 6 & 0.000 & -0.0474 & -15 & 0.470 & FSC: -0.250 \\
\hline & Within populations & 63 & 14.917 & 0.2368 & 77 & $<0.001$ & FST: 0.232 \\
\hline & Total & 70 & 18.408 & 0.3082 & & & \\
\hline & \multicolumn{7}{|l|}{ Only Azores populations } \\
\hline & Among populations & 6 & 0.000 & 0.000 & 0 & 1.000 & FST: 0.000 \\
\hline & Within populations & 28 & 0.000 & 0.000 & 0 & & \\
\hline & Total & 34 & 0.000 & 0.000 & & & \\
\hline \multirow[t]{9}{*}{ ACO1 } & \multicolumn{7}{|c|}{ Groups: Azores, outgroup (Madeira, Continental Western Palearctic) } \\
\hline & Among groups & 1 & 1.780 & 0.0250 & 6 & 0.232 & FCT: 0.061 \\
\hline & Among populations within groups & 6 & 2.905 & 0.0173 & 4 & 0.146 & FSC: 0.045 \\
\hline & Within populations & 74 & 27.461 & 0.3711 & 90 & 0.005 & FST: 0.102 \\
\hline & Total & 81 & 32.146 & 0.4134 & & & \\
\hline & \multicolumn{7}{|l|}{ Only Azores populations } \\
\hline & Among populations & 6 & 2.905 & 0.0216 & 6 & 0.147 & FST: 0.059 \\
\hline & Within populations & 39 & 13.377 & 0.3430 & 94 & & \\
\hline & Total & 45 & 16.283 & 0.3646 & & & \\
\hline
\end{tabular}


Table 4 Pairwise genetic differentiation statistics (Fst) among populations

\begin{tabular}{|c|c|c|c|c|c|c|c|c|}
\hline Gene & Place & $\begin{array}{l}\text { Oriental } \\
\text { Azores }\end{array}$ & $\begin{array}{l}\text { Central } \\
\text { Azores }\end{array}$ & Madeira & $\begin{array}{l}\text { Continental Western } \\
\text { Palearctic }\end{array}$ & $\begin{array}{l}\text { Western and eastern } \\
\text { Canary }\end{array}$ & $\begin{array}{l}\text { Gran } \\
\text { Canaria }\end{array}$ & Tenerife \\
\hline \multirow[t]{7}{*}{ CYTB } & Oriental Azores & - & & & & & & \\
\hline & Central Azores & -0.04 & - & & & & & \\
\hline & Madeira & 0.50 & 0.56 & - & & & & \\
\hline & Continental Western Palearctic & $0.31 *$ & $0.39 *$ & 0.03 & - & & & \\
\hline & Western Canary & 0.28 & $0.33 *$ & -0.09 & $0.14 *$ & - & & \\
\hline & Gran Canaria & $0.73 *$ & $0.77 *$ & $0.41 *$ & $0.34 *$ & $0.46^{*}$ & - & \\
\hline & Tenerife & $0.72 *$ & $0.76 *$ & $0.40 *$ & $0.33 *$ & $0.45 *$ & $0.52 *$ & - \\
\hline \multirow[t]{4}{*}{ ND2 } & Oriental Azores & - & & & & & & \\
\hline & Central Azores & 0.00 & - & & & & & \\
\hline & Madeira & 0.42 & 0.64 & - & & & & \\
\hline & Continental Western Palearctic & $0.21 *$ & $0.29 *$ & 0.03 & - & & & \\
\hline \multirow[t]{4}{*}{ ACO1 } & Oriental Azores & - & & & & & & \\
\hline & Central Azores & 0.00 & - & & & & & \\
\hline & Madeira & 0.01 & 0.17 & - & & & & \\
\hline & Continental Western Palearctic & 0.00 & $0.10 *$ & 0.00 & - & & & \\
\hline
\end{tabular}

Significance levels after Bonferroni correction are in bold $\left(P<0.05^{*}\right)$

\section{Morphometrics}

The MANOVA showed significant differences in morphometrics among islands (Wilks' Lambda: $0.41 \mathrm{~F}_{48}$, $491=2.05 P<0.001$; Table 5). This was the result of small differences that occurred only on São Miguel and Graciosa in three of the morphometrics: wing length from São Miguel birds were significantly larger from wing length of Graciosa $(P<0.01)$ and Faial birds $(P<0.05)$; birds from São Miguel were also significantly heavier from those of Santa Maria $(P<0.05)$ and Pico $(P<0.01)$; birds from Graciosa showed a significant smaller bill length from those of Santa Maria $(P<0.01)$, São Jorge $(P<0.05)$ and Pico $(P<0.05)$.

The CDA (Fig. 4) identified two components (root 1 and 2 ), which together accounted for $64 \%$ of the total variance. Root 1 was mainly related to bill length, bill height and body mass (Eigenvalue $=0.37 ; P<0.001$ ). Root 2 was mainly related to bill length, bill height and wing length (Eigenvalue $=0.27 ; P<0.01$ ). The percentage of individuals classified correctly into each island was 48 and 67 , respectively for Santa Maria and São Miguel, in the eastern group; 40, 58, 21, 22 and 25 respectively for Terceira, Graciosa, São Jorge, Pico and Faial, in the central group. Overall, São Miguel had a higher percentage of correct classifications, and the spatially close islands in central group had the smallest percentage (i.e., Faial, Pico and São Jorge).

\section{Discussion}

Our results revealed low genetic diversity in the Azores Islands, especially in the ND2 gene where the same haplotype was found on all the islands. The high value of the expansion coefficient shown by CYTB, together with the significant negative values of the neutrality tests, suggest a recent population expansion of Robins in this archipelago. The unimodal pairwise mismatch distribution, typical from recent expansions (see Rogers 1995), also corroborates the idea of a recent range expansion of Robins in the Azores. Moreover, the pairwise genetic differentiation, which was very small among the Azores Islands, and the topologies of the minimum spanning networks, where the Azores populations share the most common haplotypes with the other regions, support the recent colonisation of the Azores by the Robin. The recent colonisation of the Azores by passerines was already revealed for Goldcrests (Päckert et al. 2006) and Starlings (Neves et al. 2010).

The nuclear ACO1 gene revealed higher genetic diversity in the Azores populations when contrasted to the mitochondrial genes. This was expected since ancestral polymorphisms persist much longer in nuclear DNA than in mitochondrial DNA (Brown et al. 1979). Nevertheless, the high number of shared haplotypes and the Fst values between the Azores and the outgroup population corroborate the hypothesis of one recent founder event followed by a relatively fast expansion of Robins in the Azores. The 


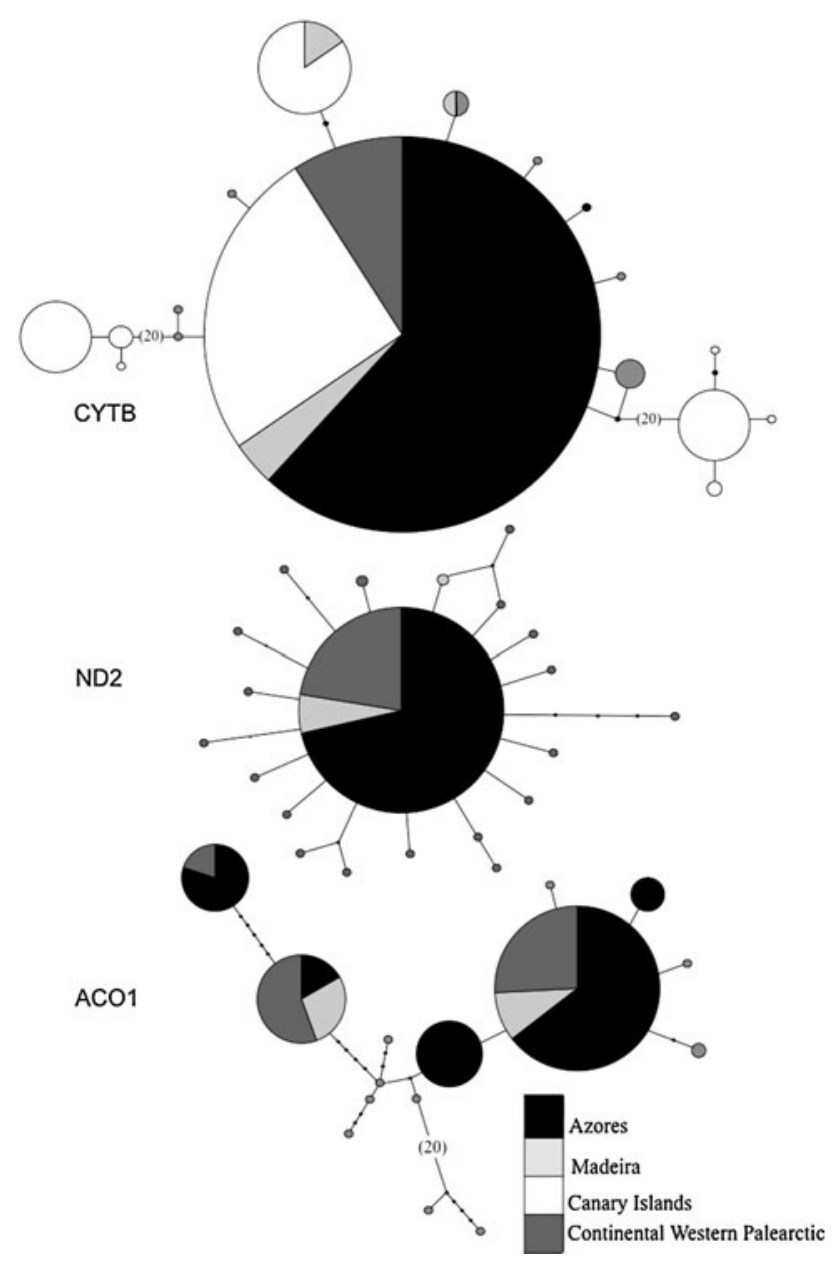

Fig. 3 Minimum spanning networks of CYTB, ND2 and ACO1 genes. Each circle represents a haplotype with the size proportional to its frequency. Dots on lines represent the number of mutational steps between two haplotypes. Number in parenthesis represents the number of mutational steps for distant samples. In CYTB network, the white circles separated by 20 mutational steps on the left are individuals from Tenerife; the white circles separated by 20 mutational steps on the right are individuals from Gran Canaria; the other white circles are from the western Canary Islands (La Palma, El Hierro and La Gomera)

bimodal pairwise mismatch distribution of ACO1 haplotypes could indicate that recent Azores founder events occurred with a subset of the already existent structure found in the Continental Western Palearctic, or due the existence of an ancient polymorphism, like it was hypothesised by Illera et al. (2011) for Blue tits from Fuerteventura and Morocco. However, the ACO1 network corroborates the hypothesis that the Azores samples share the most common haplotypes with the other regions. The slight significant positive value of Tajima's D and Fu's Fs could signify balancing selection or ancient population subdivision (Steeves et al. 2005), indicating that more studies should be made on nuclear genes.
The lack of genetic differentiation among Robin populations in the Azores Islands could be the result of their recent colonisation; therefore a sufficient time period has not passed for a possible separation of genetic lineages, leading to a uniform genetic pattern. The fact that the western group of the Azores (Flores and Corvo) has not yet been colonised provides further evidence supporting a recent colonisation event. Similar results were found for Robins from the westernmost Canary Islands (La Palma, El Hierro and La Gomera), which in contrast with Gran Canaria and Tenerife, have little genetic (based on mtDNA) and morphological differentiation (Dietzen et al. 2003).

The genetic diversity observed in the Azores was smaller than that found in other regions, probably due to their geographic isolation and/or a stronger effect of genetic drift on islands through the random fixation of alleles, as is expected for the majority of birds on isolated islands (Barton and Charlesworth 1984; Barton and Mallet 1996; Petren et al. 2005).

Statistical analysis on the measurements of the Azores Robin showed that birds from São Miguel had longer wings and higher body mass, and birds from Graciosa had the smallest bill length. These islands were also the only ones with more than $50 \%$ of birds classified correctly by the CDA model. The main driving force in the allopatric differentiation of populations is natural selection (Grant and Grant 2008) so, taking into account the lack of genetic differentiation of Robins among the Azores Islands and the evidence of a recent colonisation, the morphological differences among the Azores Islands could be related to natural selection processes that are shaping the phenotypic characters faster than neutral genes. This was also suggested for the genus Zosterops which recently colonised the Southwest Pacific islands (Clegg et al. 2002, 2010).

Dietzen et al. (2003) suggested that the colonisation of Gran Canaria and Tenerife by Robins occurred around 2.3 and 1.8 million years ago, respectively. Taking into account their results, it seems that populations from Gran Canaria and Tenerife diverged independently from Western continental Palearctic populations. It was also suggested that the colonisation of the western Canary Islands occurred in a second wave of colonisation, around 350,000 years ago, probably during the Pleistocene glaciation. Our results corroborate this recent expansion of Robins to the Atlantic islands, and suggest two hypotheses for the colonisation of the Azores, Madeira and the western Canary Islands (La Palma, El Hierro and La Gomera): (1) there was one single dispersal event from Continental Western Palearctic directly to all of this islands, similar to one of the hypotheses suggested by Marshall and Baker (1999) and Samarasin-Dissanayake (2010) for the colonisation expansion of the Chaffinch (Fringilla coelebs) into 
Table 5 Morphometric measurements of E. r. rubecula from the Azores Archipelago (mean \pm SD)

\begin{tabular}{|c|c|c|c|c|c|c|c|c|c|}
\hline Island & $\begin{array}{l}\text { Wing length } \\
(\mathrm{mm})\end{array}$ & $\begin{array}{l}\text { Tail length } \\
(\mathrm{mm})\end{array}$ & $\begin{array}{l}\text { Tarsus length } \\
(\mathrm{mm})\end{array}$ & $\begin{array}{l}\text { Head and bill } \\
\text { length }(\mathrm{mm})\end{array}$ & $\begin{array}{l}\text { Bill length } \\
(\mathrm{mm})\end{array}$ & $\begin{array}{l}\text { Bill height } \\
(\mathrm{mm})\end{array}$ & $\begin{array}{l}\text { Bill width } \\
(\mathrm{mm})\end{array}$ & $\begin{array}{l}\text { Body mass } \\
(\mathrm{g})\end{array}$ & $\mathrm{N}$ \\
\hline Santa Maria & $71.5 \pm 2.3$ & $59.3 \pm 3.2$ & $25.1 \pm 0.8$ & $33.2 \pm 0.6$ & $14.6 \pm 0.8$ & $3.6 \pm 0.2$ & $4.3 \pm 0.3$ & $16.1 \pm 1.2$ & 23 \\
\hline São Miguel & $73.0 \pm 2.3$ & $59.0 \pm 3.2$ & $24.8 \pm 0.8$ & $33.3 \pm 0.6$ & $14.1 \pm 0.8$ & $3.5 \pm 0.2$ & $4.3 \pm 0.3$ & $17.1 \pm 1.2$ & 33 \\
\hline Terceira & $71.6 \pm 1.7$ & $59.2 \pm 2.2$ & $24.2 \pm 0.8$ & $33.1 \pm 0.8$ & $13.6 \pm 1.1$ & $3.6 \pm 0.3$ & $4.5 \pm 0.2$ & $16.1 \pm 1.2$ & 5 \\
\hline Graciosa & $70.0 \pm 1.8$ & $56.8 \pm 2.5$ & $24.6 \pm 0.8$ & $32.9 \pm 0.2$ & $13.5 \pm 0.8$ & $3.5 \pm 0.1$ & $4.2 \pm 0.2$ & $16.4 \pm 0.9$ & 12 \\
\hline São Jorge & $71.3 \pm 2.1$ & $57.6 \pm 2.7$ & $25.0 \pm 0.8$ & $33.1 \pm 0.5$ & $14.4 \pm 0.8$ & $3.6 \pm 0.3$ & $4.3 \pm 0.2$ & $16.3 \pm 1.5$ & 19 \\
\hline Pico & $72.0 \pm 1.6$ & $58.6 \pm 2.7$ & $24.4 \pm 0.6$ & $33.1 \pm 0.3$ & $14.6 \pm 0.3$ & $3.5 \pm 0.3$ & $4.2 \pm 0.3$ & $15.4 \pm 1.2$ & 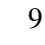 \\
\hline Faial & $70.6 \pm 1.9$ & $57.4 \pm 2.8$ & $24.5 \pm 1.1$ & $32.9 \pm 0.8$ & $14.3 \pm 0.7$ & $3.4 \pm 0.3$ & $4.2 \pm 0.5$ & $16.2 \pm 0.6$ & 12 \\
\hline $\begin{array}{c}P \text { (One-way } \\
\text { ANOVA) }\end{array}$ & 0.001 & 0.112 & 0.069 & 0.486 & 0.003 & 0.122 & 0.270 & 0.003 & \\
\hline
\end{tabular}

For each measurement it is also shown the statistical significance of significant differences among islands using One-way ANOVA

Significant $P$ level showed in bold

Fig. 4 Plot of the Canonical Discriminant Analysis centroids (mean $\pm \mathrm{SD}$ ) of root 1 versus root 2 scores with the percentage of variance explained by each root. Axis units are scaled to the ratio of proportion of variance described by the roots. FAI-Faial, PICPico, SJO—São Jorge, GRAGraciosa, TER-Terceira, SMI-São Miguel, SMASanta Maria

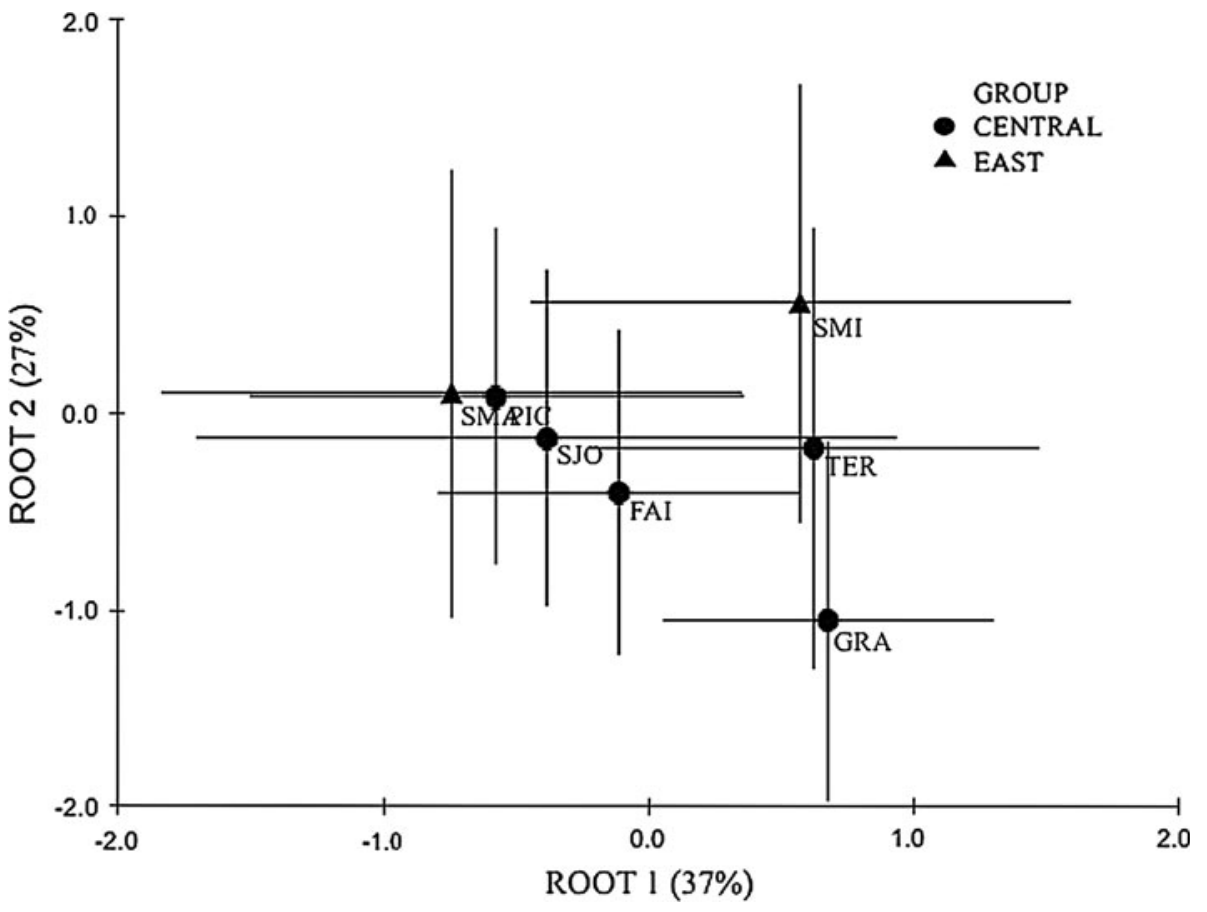

the Atlantic islands; (2) there was one first dispersal event from the Continental Western Palearctic to the Canary Islands and/or Madeira, from which they colonised the Azores, in the last 80,000 years [based on the 2.1 molecular rate (Weir and Schluter 2008)]. This second hypothesis seems to be the most probable one, based on the Fst values among those regions, and also because birds from the three Macaronesian archipelagos shared the most common haplotype, and the western Canary Islands and the Madeira birds present a higher percentage of private haplotypes. The same pattern was found for the expansion of Serinus canaria into Macaronesia (Dietzen et al. 2006). The routes of colonisation within the Azores islands are not obvious since all the islands shared the most common haplotype, but taking into account our networks, it seems that a fast radiation occurred among the islands from the east and central groups. Based on the Fst values, the age of each island, and their geographic position, it is more likely that the Robin first arrived to the east group islands and then radiated to the central group.

Our genetic and morphometric data give no indication for an obvious differentiation among Robin populations within the western Canary Islands, Madeira and the Azores, indicating their relatively recent colonisation followed by a subsequent rapid radiation. This recent colonisation could be the reason for the absence of Robins in the westernmost islands (Corvo and Flores). More comprehensive datasets of neutral variation in nuclear autosomal genes and fast 
evolving regions (e.g., microsatellites) are necessary in order to understand the radiation of this species within the Azores islands.

Acknowledgments We would like to thank the Direção Regional do Ambiente dos Açores for their kind permission to capture birds and collect blood samples from the Azores (permission 119/2011/ DRA). To Parque Natural da Madeira for the permission to take samples from Madeira (permission 01-A/2011/FAU/MAD). To Instituto da Conservação da Natureza e da Biodiversidade for the ring permission (152/2011). To Jan Lifjeld and the National Centre for Biosystematics team of the Natural History Museum of Oslo for their support during the field trip to Madeira. To Joana Micael and Roberto Resendes for their support in the field; to Paulo Tenreiro for collecting samples from Portugal; and to André Eloy, Associação de Juventude da ilha Graciosa, Atlânticoline, Bárbara Gravanita, Grupo Bensaude, EDA, Even Stensrud, Fernando Cunha, João Melo, José Marcelino, Pedro Domingues and Robin Kersten for their support along the Azores Islands. To Nicolle Mode and Therese Catanach for the English revision of this manuscript. P Rodrigues and RJ Lopes were supported by grant funding from FCT - Portuguese Foundation for Science and Technology (SFRH/BD/36084/2007 and SFRH/BPD/ $40786 / 2007$ respectively). The study was also partially supported by FCT project PTDC/BIA-BEC/103435/2008 to S. Drovetski. All the conducted experiments comply with the current laws of Portugal and the authors declare that they have no conflict of interest.

\section{References}

Arctander P, Folmer O, Fjeldsa J (1996) The phylogenetic relationships of Berthelot's pipit Anthus berthelotti illustrated by DNA sequence data, with remarks on the genetic distance between Rock and Water pipits Anthus spinoletta. Ibis 138:263-272

Bannerman DA, Bannerman WN (1966) Birds of the Atlantic Islands. vol. 3: a history of the birds of the Azores. Oliver and Boyd, Edinburgh

Barton NH, Charlesworth B (1984) Genetic revolutions, founder effects, and speciation. Annu Rev Ecol Sys 15:133-164

Barton NH, Mallet J (1996) Natural selection and random genetic drift as causes of evolution on islands (and discussion). Phil Trans R Soc B 351:785-795

Bergmann H, Schottler B (2001) Tenerife Robin-a species of its own? Dutch Birding 23:140-146

Brown WM, George MJR, Wilson AC (1979) Rapid evolution of animal mitochondrial DNA. Proc Natl Acad Sci USA 74:1967-1971

Clarke T, Orgill C, Disley T (2006) Field guide to the birds of the Atlantic Islands: Canary Islands, Madeira, Azores. Helm Field Guides, Cape Verde

Clegg SM, Phillimore A (2010) The influence of gene flow and drift on genetic and phenotypic divergence in two species of Zosterops in Vanuatu. Phil Trans R Soc B 365:1077-1092

Clegg SM, Degnan CM, Estoup A, Kikkawa J, Owens IPF (2002) Microevolution in island forms: the roles of drift and directional selection in morphological divergence of a passerine bird. Evolution 56:2090-2099

Clement M, Posada D, Crandall KA (2000) TCS: a computer programme to estimate gene genealogies. Mol Ecol 9:1657-1660

Clements JF (2000) Birds of the World. A checklist. Pica Press, Sussex

Cramp S (1988) Handbook of the birds of Europe, the Middle East and North Africa. The birds of the Western Palearctic. vol 5:
Tyrant flycatchers to thrushes. Oxford University Press, Oxford, UK

del Hoyo J, Elliott A, Christie D (2006) Handbook of the birds of the world. Vol. 11: old world Flycatchers to old world warblers. Lynx Editions, Barcelona, Spain

Dietzen C, With HH, Wink M (2003) The phylogeographic differentiation of the European Robin Erithacus rubecula on the Canary Islands revealed by mitochondrial DNA sequence data and morphometrics: evidence for a new Robin taxon on Gran Canaria? Avian Sci 3:115-131

Dietzen C, Voigt C, Wink M, Gahr M, Leitner S (2006) Phylogeography of island canary (Serinus canaria) populations. J Ornithol 147:485-494

Equipa Atlas (2008) Atlas das Aves Nidificantes em Portugal (1999-2005). Instituto da Conservação da Natureza e da Biodiversidade, Sociedade Portuguesa para o Estudo das Aves, Parque Natural da Madeira e Secretaria Regional do Ambiente e do Mar. Assírio \& Alvim, Lisboa, Portugal

França Z, Cruz JV, Nunes JC, Forjaz VH (2003) Geologia dos Açores: uma perspectiva actual. Açoreana 10:11-140

Fu YX (1997) Statistical tests of neutrality of mutations against population growth, hitchhiking and background selection. Genetics 147:915-925

Fu YX, Li WH (1993) Statistical test of neutrality of mutations. Genetics 133:693-709

Grant P, Grant R (2008) How and why species multiply. The radiation of Darwin's finches. Princeton University Press, New Jersey

Harpending HC (1994) Signature of ancient population growth in a low-resolution mitochondrial DNA mismatch distribution. Hum Biol 66:591-600

Hartert JC, Olgivie-Grant WR (1905) On the birds of the Azores. Novi Zool 12:80-128

Helbig AJ, Martens J, Henning F, Schottler B, Seibold I, Wink M (1996) Phylogeny and species limits in the Palaearctic Chiffchaff Phylloscopus collybita complex: mitochondrial genetic differentiation and bioacoustic evidence. Ibis 138:650-666

Hounsome MC (1993) Biometrics and origins of some Atlantic island birds. Bol Mus Mun Funchal 2:107-129

Illera JC, Koivula K, Broggi J, Päckert M, Martens J, Kvist L (2011) A multi-gene approach reveals a complex evolutionary history in the Cyanistes species group. Mol Ecol 20:4123-4139

Librado P, Rozas J (2009) DnaSP v5: a software for comprehensive analysis of DNA polymorphism data. Bioinformatics 25:14511452

Marshall HD, Baker AJ (1999) Colonisation History of Atlantic Island Common Chaffinches (Fringilla coelebs) Revealed by Mitochondrial DNA. Mol Phylogenet Evol 11:201-212

Martin A, Lorenzo JA (2001) Aves del Archipélago Canario. Francisco Lemus, Editor SL. La Laguna, Tenerife

Nei M (1987) Molecular evolutionary genetics. Columbia University Press, New York

Neves VC, Griffiths K, Savory FR, Furness RW, Mable BK (2010) Are European starlings breeding in the Azores archipelago genetically distinct from birds breeding in mainland Europe? Eur J Wild Res 59:95-100

Päckert M, Martens J (2004) Song dialects on the Atlantic islands: goldcrests of the Azores (Regulus regulus azoricus, $R . r$. sanctae-mariae, $R$. r. inermis). J Ornithol 145:23-30

Päckert M, Dietzen C, Martens J, Wink M, Kvist L (2006) Radiation of Atlantic Goldcrests Regulus regulus spp.: evidence of a new taxon from the Canary Islands. J Avian Biol 37:364-380

Peck DR, Congdon BC (2004) Reconciling historical biogeography of the Catharus thrushes: a molecular phylogenetic approach. Auk 120:299-310

Pérez-Tris J, Carbonell R, Tellería JL (2000) Abundance distribution, morphological variation and juvenile condition of Robins, 
Erithacus rubecula (L.), in their Mediterranean range boundary. J Biogeogr 27:879-888

Petren K, Grant PR, Grant BR, Keller LF (2005) Comparative landscape genetics and the adaptive radiation of Darwin's finches: the role of peripheral isolation. Mol Ecol 14:2943-2957

Ramos-Onsins SE, Rozas J (2002) Statistical properties of new neutrality test against population growth. Mol Biol Evol 19:2092-2100

Rodrigues P, Bried J, Rodebrand S, Cunha R (2010) AVES. In: Borges PAV, Costa A, Cunha R, Gabriel R, Gonçalves V, Martins AF, Melo I, Parente M, Raposeiro P, Rodrigues P, Santos RS, Silva L, Vieira P, Vieira V (eds) A list of the terrestrial and marine biota from the Azores. Princípia, Cascais

Rogers AR (1995) Genetic evidence for a Pleistocene population explosion. Evolution 49:608-615

Samarasin-Dissanayake P (2010) Population differentiation, historical demography and evolutionary relationships among widespread Common Chaffinch populations (Fringilla coelebs ssp.). Thesis for the degree of Master of Science, University of Toronto

Schneider S, Roessli D, Excoffier L (2000) Arlequin: a software for population genetics data analysis. User manual ver 2.000 . Genetics and Biometry Laboratory Department of Anthropology, University of Geneva, Geneva, Italy

StatSoft Inc (2007) STATISTICA (data analysis software system), version 8.0. www.statsoft.com

Steeves TE, Anderson DJ, Friesen VL (2005) The isthmus of Panama: a major physical barrier to gene flow in a highly mobile pantropical seabird. J Evol Biol 18:1000-1008
Suárez NM, Betancor E, Klassert TE, Almeida T, Hernández M, Pestano JJ (2009) Phylogeography and genetic structure of the Canarian common Chaffinch (Fringilla coelebs) inferred with mtDNA and microsatellite loci. Mol Phylogenet Evol 53:556-564

Svensson L (1992) Identification guide to European Passerines. L. Svensson, Stockholm

Tajima F (1989) Statistical method for testing the neutral mutation hypothesis by DNA polymorphism. Genetics 123:585-595

Tajima F (1996) The amount of DNA polymorphism maintained in a finite population when the neutral mutation rate varies among sites. Genetics 143:1457-1465

Thompson B (1991) Methods, plainly speaking: a primer on the logic and use of canonical correlation analysis. Mes Eval Couns Dev 24:80-93

von Haeseler A, Sajantila A, Paabo S (1996) The genetical archaeology of the human genome. Nat Genet 14:135-140

Weir JT, Schluter D (2008) Calibrating the avian molecular clock. Mol Ecol 17:2321-2328

Wink M, Sauer-Gürth H, Gwinner E (2002) Evolutionary relationships of stonechats and related species inferred from mitochondrial-DNA sequences and genomic fingerprinting. Brit Birds 95:349-355

Wittmann U, Heidrich P, Wink M, Gwinner E (1995) Speciation in the stonechat Saxicola torquata inferred from nucleotide sequences of the cytochrome-b gene. J Zoo Syst Evol Res 33:116-122

Zar JH (1999) Biostatistical analysis, 4th edn. Prentice Hall, New Jersey 